\title{
Economic returns of practicing tennis on private clubs.
}

\section{Labib Abdel Aziz Labib}

Assistant Professor, Department of Basics of Physical Education, Faculty of Physical Education - Menoufia University. Egypt.

\begin{abstract}
The study aims to identify the economic return of tennis in private clubs throughout three domains, Financial domain, Technical domain and Facilities and capabilities, The researcher used the descriptive method which is appropriate to the nature of the study, The total samples of tennis players and parents were 82 individual, selected from private tennis clubs. Table (1) shows the characterization of the sample, Playing tennis at the private clubs achieves the following financial returns, Providing special paid training sessions, The financial profits attain by the restaurants and cafeterias of the club, Profits achieve by renting the tennis courts, There is an increases of demand for membership in the club because of the presence of tennis courts, Playing tennis in private clubs realize financial return through the following, Provide special paid training for players, Renting tennis courts , Marketing for tennis gears, Advertisements of the club , The restaurants and cafeterias that provide services for members, Organizing tennis championships, There is an increases of demand for membership in the club .
\end{abstract}

\section{Introduction}

$\mathrm{S}$ port is a significant part of the structure of society because of what it represents of cultural progress which is crystal clear in its economic and political considerations as sport is affected by science and technology in which it plays an important role because it accomplish great tasks. Whereas sport has become an economic industry nowadays as it need a huge capital and it couldn't be separated from the economic, social and political systems.

Today, the political administration is moving to change the Egyptian economy from central planning system to free economy system where the private sector will undertake the management of the non-profit projects. From this standpoint, the state has encouraged private investments in various fields, including the sport field, where the private sector plays a significant role in funding sport activities which reduce the burden of affording huge costs on the state that may lead to strain the state budget (2).

The sports clubs are important educational institutions that are interested in developing the community through the provision of programs and plans for its members in various sport and social fields. Private sports clubs can be one of the areas of investment that increase national economy of the state where Kemal Dervis (2004) confirmed that the development of sports in clubs should take advantage of modern management and application of its arts, sciences and secrets that are only known by talented professionals, so knowledge of sport science become important in order to be able to deal with the changes of the new century and technological development (5). 
The contribution of the economic system on sport depends on the philosophy and the approach of the ruling political system, as well as the support it receives from this system and the types of beliefs of the society (4).

The sports system is based on economic pillars represented in the budgets of the activities and programs as well as tools and systems and wages of cadres in addition to bonuses and incentives of players. Therefore, the relationship between sport and economy is related to the fact that sport depend on economy to finance the various aspects of the activity, and it is related to supporting the commercial interests and consumer of sport as a source of profit. Most of the economic problems in sport are found in the continuous intention to acquire a financial support from the country to pay for all aspects of the sport activity. In light of the lack of resources in the developing communities and their ability to spend money which laid upon the burden of the state and it inability to fully meet its obligations of organizing distinct sports activities at all levels (3).

The capitalist economic system is based on freedom in all economic, social, and political areas, beside it focuses on the principle of private property, freedom of contract and freedom of economic decision (6).

The researcher believes that the permanent trust of sport sector on the governmental support and subsidies for long periods should reconsider the economic management of the sport, especially some sport games such as tennis. In light of the shrinking budget of sports and the state's inability to meet the needs of the preparation of stars and that private clubs could achieve economic returns through what they offer of modern facilities and capabilities that lead to the upgrading of the activity without the state bears the financial burdens, so that the number of stars of tennis does not depend on the country and does not constitute a burden on the budget of the state. The involvement of the private sector in the investment of the sports sector makes them more anxious to sponsored this investment and develop it, as well as ensure its renewal and searching for new technologies that make it in the forefront, where services of high values are provided in return of a margin of profit that is accepted by the player and leads him to a higher skillful level.

\section{The research problem and its importance}

The Egyptian clubs face many problems due to the increased number of members who practice activities within few and weak capabilities available to these clubs and because of the large costs of the number of stars in the sports field, in addition to, the decrease of governmental support. All these factors had led to the inability of those clubs to prepare stars and this led to the low performance in national and international championships. In order to solve this problem, the government opened the way for clubs in Egypt, aiming at provide high level sport services in return for economic returns as a result of providing these services, and provide a good sports environment e.g. courts, halls and high level modern training programs.

More recently, the researcher noted throughout his work in the field of tennis, a large spread of private clubs that depend on tennis as its main activities because it attracts the highest economic classes of the society. These clubs lunched their activities with Smash Academy Club (Cairo airport branch) which afterward expanded to contain five branches in Cairo as well as Wadi Degla Club and other clubs which approximately 
reach forty Private Clubs. These clubs had been established without neither governmental support nor waiting for financial support and there is an increasing demand for membership in these clubs especially tennis players until the non-private sport clubs compete in providing training services and standard courts. These clubs compete with each other in organizing championships and competitions supervised by the Tennis Egyptian Federation on the national and international level.

The researcher noticed also, throughout his academic work in the Faculty of Physical education, that there is an increasing demand from most students to practice tennis which lead the research to study this phenomena to identify the economic return on private clubs and its workers which depend on tennis as its main activity through studying what facilities and capabilities they offer as well as the technical programs and the benefits gain as a result of providing these services.

\section{Objective of the research:}

The current research aims to identify the economic return of tennis in private clubs throughout three domains: -

1. Financial domain

2. Technical domain

3. Facilities and capabilities

\section{The Methodology}

The descriptive method which is appropriate to the nature of the study, Which describes the current situation and illustrates the economic return of the practice of the sport of tennis

\section{The sample:}

\section{First: Tennis players and parents sample:}

The research was conducted on a sample of tennis players over 16 years old and their parents who represent the private clubs. The following are the prerequisites of the samples

1. Not less than one year as an active member in the Club

2. Be a minimum of 16 years of age

3. To represent the private club which he is a member in tennis team

4. At least three years had passed since the foundation of the club

The total samples of tennis players and parents were 82 individual, selected from private tennis clubs. Table (1) shows the characterization of the sample.

\section{Second: Coaches and officials samples}

The coaches and officials sample was selected from those working in private clubs according to the following conditions:

1. Have a minimum of a completed secondary school education

2. Minimum of one year of active working at the club

3. Be a minimum of 25 years of age 
Table (1)

The basic study sample of players, parents and coaches

\begin{tabular}{|c|c|c|c|}
\hline S & Club name & $\begin{array}{c}\text { Players and parents } \\
\text { sample }\end{array}$ & $\begin{array}{c}\text { Coaches and officials } \\
\text { sample }\end{array}$ \\
\hline 1 & Smash Tennis Academy - Airport branch & 18 & 5 \\
\hline 2 & Smash Pearl Tennis - 6 ${ }^{\text {th }}$ of October & 7 & 2 \\
\hline 3 & Katameya Heights Tennis Resort & 4 & 5 \\
\hline 4 & Wadi Degla Maadi Club & 14 & 2 \\
\hline 5 & Golf Solimania Club & 3 & 2 \\
\hline 6 & Balmar Al Arosy Club & 11 & 3 \\
\hline 7 & Golf City Al Obour Club & 9 & 2 \\
\hline 8 & City Stars Academy Club & 4 & 2 \\
\hline 9 & Dream Land Club & 5 & 2 \\
\hline 10 & Beverly Hills Club & 4 & 1 \\
\hline 11 & Wadi Degla Katameya Club & 82 & 28 \\
\hline
\end{tabular}

\section{Data collection tools}

The researcher has prepared two questionnaires, one for the players and their parents and the other for coaches and officials. The researcher had conducted interview with the personnel in charge of the private clubs and players as well as referring to the studies on the economic returns from practicing sports activities in order to set up the initial form of the questionnaire and the proposed domains in addition to the appropriateness of the statements with each domain and the aim of the research. All these things were presented to the judges who have been selected from experts in the field of tennis.

Table (4)

The domains of the questionnaires and the number of statements for each domain

\begin{tabular}{|c|c|c|c|c|c|}
\hline \multirow{2}{*}{$S$} & \multirow{2}{*}{ Domain of the questionnaires } & \multicolumn{2}{c|}{$\begin{array}{c}\text { Players and parents } \\
\text { questionnaire }\end{array}$} & \multicolumn{2}{c|}{$\begin{array}{c}\text { Coaches and officials } \\
\text { questionnaire }\end{array}$} \\
\cline { 3 - 6 } & & $\begin{array}{c}\text { Serial of the } \\
\text { statements }\end{array}$ & $\begin{array}{c}\text { Number of } \\
\text { statements }\end{array}$ & $\begin{array}{c}\text { Serial of the } \\
\text { statements }\end{array}$ & $\begin{array}{c}\text { Number of } \\
\text { statements }\end{array}$ \\
\hline 1 & Financial domain & $12-1$ & 12 & $10-1$ & 10 \\
\hline 2 & Technical domain & $28-13$ & 16 & $22-11$ & 12 \\
\hline 3 & Facilities and capabilities & $45-29$ & 17 & $37-23$ & 15 \\
\hline \multicolumn{2}{r|}{ Total sentences } & & 45 & & 37 \\
\hline
\end{tabular}

The Reliability of the questionnaire:

The reliability coefficient of the questionnaires through the application calculates on a sample of the players and 
parents of 13 individual and a sample of coaches and officials of (9) individual outside the research sample and then reapplies on the same sample after 15 days of the first application.

\section{The application of the questionnaire}

After making sure of the scientific coefficient for both questionnaire (players \& parents questionnaire, coaches and officials questionnaire), the researcher prepared them in their final form and apply them during the championships held on the following clubs: Al Seed Club $6^{\text {th }}$ of October, AL Solimania, and Wadi Degla Maadi Club during January 2013.

\section{Presenting and discussing the results:}

Table (5)

The statistical descriptions and the percentages of the sample's answers from players and parents on the financial domain

\begin{tabular}{|c|c|c|c|c|c|c|c|c|c|c|c|c|}
\hline \multirow{2}{*}{$\mathbf{S}$} & \multirow{2}{*}{ Questionnaire statements } & \multicolumn{2}{|c|}{ Yes } & \multicolumn{2}{|c|}{$\begin{array}{l}\text { To some } \\
\text { extend }\end{array}$} & \multicolumn{2}{|c|}{ No } & \multirow{2}{*}{ 芯 } & \multirow{2}{*}{$\stackrel{\overrightarrow{0}}{\dot{\vec{n}}}$} & \multirow{2}{*}{ 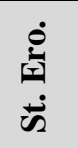 } & \multirow{2}{*}{ 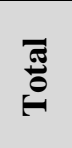 } & \multirow{2}{*}{$\%$} \\
\hline & & No. & $\%$ & No. & $\%$ & No. & $\%$ & & & & & \\
\hline 1 & $\begin{array}{l}\text { Practicing tennis realize } \\
\text { profits for the club }\end{array}$ & 51 & 62.2 & 28 & 34.1 & 3 & 3.7 & 2.58 & 0.56 & 0.98 & 212 & 86 \\
\hline 2 & $\begin{array}{l}\text { Marketing for sport gear is } \\
\text { fully done through the activity } \\
\text { of tennis }\end{array}$ & 24 & 29.3 & 31 & 37.8 & 27 & 32.9 & 1.96 & 0.79 & 0.66 & 161 & 65 \\
\hline 3 & $\begin{array}{l}\text { The club realizes huge profits } \\
\text { by selling tennis instruments }\end{array}$ & 19 & 23.3 & 45 & 54.9 & 18 & 22 & 2.01 & 0.68 & 0.14 & 165 & 67 \\
\hline 4 & $\begin{array}{c}\text { Club realize revenues through } \\
\text { renting Tennis Courts }\end{array}$ & 56 & 68.3 & 26 & 31.7 & - & - & 2.68 & 0.47 & 0.80 & 220 & 89 \\
\hline 5 & $\begin{array}{l}\text { There is an increases of } \\
\text { demand for membership in } \\
\text { the club because of the } \\
\text { presence of tennis courts }\end{array}$ & 50 & 61.0 & 29 & 35.4 & 3 & 3.7 & 2.57 & 0.57 & 0.92 & 211 & 86 \\
\hline 6 & $\begin{array}{l}\text { Financial return of tennis } \\
\text { activity helps in setting up and } \\
\text { maintenance of the courts }\end{array}$ & 67 & 81.7 & 15 & 18.3 & - & - & 2.82 & 0.40 & 1.67 & 231 & 94 \\
\hline 7 & $\begin{array}{c}\text { There are ads at the club } \\
\text { which realize an appropriate } \\
\text { financial income }\end{array}$ & 15 & 18.3 & 55 & 67.1 & 12 & 14.6 & 2.04 & 0.58 & 0.03 & 176 & 72 \\
\hline 8 & $\begin{array}{c}\text { The restaurants and cafeterias } \\
\text { of the club realize financial } \\
\text { profits }\end{array}$ & 76 & 92.7 & 6 & 7.3 & - & - & 2.93 & 0.26 & 3.34 & 240 & 98 \\
\hline 9 & $\begin{array}{c}\text { There are paid private } \\
\text { training sessions in the club }\end{array}$ & 77 & 93.9 & 5 & 6.1 & - & - & 2.94 & 0.24 & 3.74 & 241 & 78 \\
\hline 10 & $\begin{array}{c}\text { Tennis championships realize } \\
\text { great revenues for the club }\end{array}$ & 10 & 12.2 & 60 & 73.2 & 12 & 14.6 & 1.98 & 0.52 & 0.35 & 162 & 66 \\
\hline 11 & $\begin{array}{c}\text { The club offers financial } \\
\text { incentives for winners of } \\
\text { tennis championships }\end{array}$ & 32 & 39 & 15 & 18.3 & 35 & 42.7 & 1.96 & 0.91 & 0.73 & 161 & 65 \\
\hline 12 & $\begin{array}{l}\text { Annual fees of the club are } \\
\text { reasonable for members }\end{array}$ & 41 & 50 & 27 & 32.9 & 14 & 17.1 & 2.33 & 0.75 & 0.63 & 191 & 78 \\
\hline
\end{tabular}


Table (5) shows the answers of the sample of players and parents on the financial domain which clarify that the sentences that obtain high marks were as follow:

- There are paid private training sessions in the club

- The restaurants and cafeterias of the club realize financial profits

- Financial return of tennis activity helps in setting up and maintenance of the courts

- Club realize revenues through renting tennis Courts

- Practicing tennis realize profits for the club

- There is an increases of demand for membership in the club because of the presence of tennis courts
All of the above confirm the realization of a suitable financial return through tennis activities.

While the sentences that obtain low marks were as follow:

- The club offers financial incentives for winners of tennis championships

- Marketing for sport gear is fully done through the activity of tennis

- There are ads at the club which realize an appropriate financial income

This clarifies that there is no enough care given to the players and there is a weak marketing for sports gears, in addition, tennis championships doesn't realize huge financial returns as well as the advertisements are used in marketing for the club without being an important source of profit.

Table (6)

The statistical descriptions and the percentages of the sample's answers from players and parents on the technical domain

\begin{tabular}{|c|c|c|c|c|c|c|c|c|c|c|c|c|}
\hline \multirow[t]{2}{*}{$\mathbf{S}$} & \multirow[t]{2}{*}{ Questionnaire statements } & \multicolumn{2}{|c|}{ Yes } & \multicolumn{2}{|c|}{$\begin{array}{l}\text { To some } \\
\text { extend }\end{array}$} & \multicolumn{2}{|c|}{ No } & \multirow{2}{*}{ 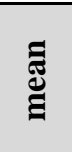 } & \multirow{2}{*}{ 苛 } & \multirow{2}{*}{ 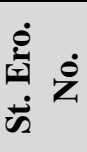 } & \multirow{2}{*}{ 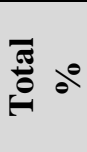 } & \multirow[t]{2}{*}{ \& $\dot{\mathbf{z}}$} \\
\hline & & No. & $\%$ & No. & $\%$ & No. & $\%$ & & & & & \\
\hline 13 & $\begin{array}{l}\text { Training programs for tennis } \\
\text { on the club are well prepared }\end{array}$ & 48 & 58.5 & 34 & 45.5 & - & - & 2.59 & 0.50 & 0.35 & 212 & 86 \\
\hline 14 & $\begin{array}{l}\text { The club offers qualified } \\
\text { coaches for tennis players }\end{array}$ & 43 & 52.4 & 39 & 47.5 & - & - & 2.42 & 0.50 & 0.1 & 207 & 84 \\
\hline 15 & $\begin{array}{c}\text { Training programs help players } \\
\text { to reach higher skillful level }\end{array}$ & 29 & 35.4 & 41 & 50 & 12 & 14.6 & 2.21 & 0.68 & 0.28 & 181 & 74 \\
\hline 16 & $\begin{array}{l}\text { There are training programs in } \\
\text { the club for high level players }\end{array}$ & 33 & 40.2 & 27 & 32.9 & 22 & 26.8 & 2.13 & 0.81 & 0.25 & 175 & 71 \\
\hline 17 & $\begin{array}{l}\text { Highly qualified coaches are } \\
\text { responsible for training players }\end{array}$ & 32 & 39 & 42 & 51.2 & 8 & 9.8 & 2.29 & 0.64 & 0.34 & 188 & 76 \\
\hline 18 & $\begin{array}{l}\text { Training program at the club } \\
\text { consider the academic periods } \\
\text { of the players }\end{array}$ & 27 & 32.9 & 33 & 40.2 & 22 & 26.8 & 2.16 & 0.78 & 0.11 & 169 & 69 \\
\hline 19 & $\begin{array}{l}\text { The training programs help } \\
\text { players to participate in the } \\
\text { championships }\end{array}$ & 54 & 65.9 & 28 & 34.1 & - & - & 2.66 & 0.48 & 0.68 & 218 & 89 \\
\hline 20 & $\begin{array}{l}\text { The club administration } \\
\text { continuously follow up the } \\
\text { technical level of the players }\end{array}$ & 18 & 22 & 45 & 54.9 & 19 & 23.2 & 1.99 & 0.68 & $\begin{array}{c}0.01 \\
4\end{array}$ & 163 & 66 \\
\hline
\end{tabular}




\begin{tabular}{|c|c|c|c|c|c|c|c|c|c|c|c|c|}
\hline \multirow[t]{2}{*}{$\mathbf{S}$} & \multirow{2}{*}{ Questionnaire statements } & \multicolumn{2}{|c|}{ Yes } & \multicolumn{2}{|c|}{$\begin{array}{c}\text { To some } \\
\text { extend }\end{array}$} & \multicolumn{2}{|c|}{ No } & \multirow{2}{*}{ 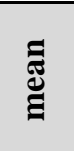 } & \multirow{2}{*}{ 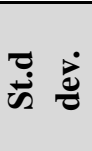 } & \multirow{2}{*}{ 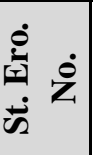 } & \multirow{2}{*}{$\stackrel{\sigma}{\pi}_{0}^{0}$} & \multirow{2}{*}{ \& } \\
\hline & & No. & $\%$ & No. & $\%$ & No. & $\%$ & & & & & \\
\hline 21 & $\begin{array}{l}\text { The club follow up the players } \\
\text { during their participation in } \\
\text { competition and championships }\end{array}$ & 46 & 56.1 & 23 & 28 & 13 & 15.9 & 2.4 & 0.75 & 0.82 & 197 & 80 \\
\hline 22 & $\begin{array}{c}\text { The club organize internal } \\
\text { competition to identify the level } \\
\text { of the players }\end{array}$ & 36 & 43.9 & 12 & 14.6 & 34 & 41.5 & 2.02 & 0.93 & 0.49 & 166 & 67 \\
\hline 23 & $\begin{array}{l}\text { The club uses modern methods } \\
\text { in training }\end{array}$ & 23 & 28 & 28 & 34.1 & 31 & 37.8 & 1.9 & 0.81 & $\begin{array}{c}0.18 \\
2\end{array}$ & 156 & 63 \\
\hline 24 & $\begin{array}{l}\text { The club conduct periodical } \\
\text { examinations to identify the } \\
\text { level of the players }\end{array}$ & 37 & 45.1 & 35 & 42.7 & 10 & 12.2 & 2.33 & 0.69 & $\begin{array}{c}0.53 \\
2\end{array}$ & 191 & 78 \\
\hline 25 & $\begin{array}{l}\text { The club supports the players } \\
\text { to take part in the international } \\
\text { championships }\end{array}$ & 25 & 30.5 & 32 & 39 & 25 & 30.5 & 2.00 & 0.78 & -- & 164 & 67 \\
\hline 26 & $\begin{array}{l}\text { The educational videos are used } \\
\text { in coaching the club's members }\end{array}$ & 23 & 28 & 10 & 12.2 & 49 & 59.8 & 1.68 & 0.88 & 0.68 & 138 & 56 \\
\hline 27 & $\begin{array}{l}\text { The club provides fitness } \\
\text { coaches for players }\end{array}$ & 61 & 74.4 & 21 & 25.6 & - & - & 2.74 & 0.44 & 1.14 & 225 & 91 \\
\hline 28 & $\begin{array}{c}\text { The club offers specialist for the } \\
\text { rehabilitation of injuries and } \\
\text { treatment }\end{array}$ & 28 & 34.1 & 45 & 54.9 & 9 & 11 & 2.23 & 0.63 & 0.23 & 183 & 74 \\
\hline
\end{tabular}

Table (6) shows the answers of the sample of players and parents on the technical domain. The following are the sentences that obtain high marks:

- The club provides fitness coaches for players

- The training programs help players to participate in the championships

- Training programs for tennis on the club are well prepared

- The club offers qualified coaches for tennis players

The research noticed that all of the above is related to their keenness to continue and attain success.

While the statements that obtain low marks were as follow:

- The educational videos are used in coaching
- The club uses modern methods in training

- The club administration continuously follow up the technical level of the players

- The club supports the players to take part in the international championships

- The club organizes internal competition to identify the level of the players

- Training program at the club consider the academic periods of the players.

The researcher clarifies that the club is much interested in making profit and there is no coordination between educational programs in schools and training programs and he emphasizes on the necessity to take care of all these aspects. $(1)(7)(9)(10)(11)(12)(13)$. 
Table (7)

The statistical descriptions and the percentages of the sample's answers from players and parents on the facility and capabilities domain

\begin{tabular}{|c|c|c|c|c|c|c|c|c|c|c|c|c|}
\hline \multirow{2}{*}{$\mathbf{S}$} & \multirow{2}{*}{ Questionnaire statements } & \multicolumn{2}{|c|}{ Yes } & \multicolumn{2}{|c|}{$\begin{array}{l}\text { To some } \\
\text { extend }\end{array}$} & \multicolumn{2}{|c|}{ No } & \multirow{2}{*}{ 芯 } & \multirow{2}{*}{ 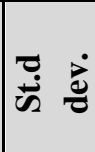 } & \multirow{2}{*}{ 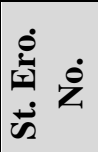 } & \multirow{2}{*}{ 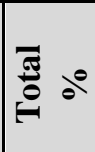 } & \multirow{2}{*}{$\therefore$} \\
\hline & & No. & $\%$ & No. & $\%$ & No. & $\%$ & & & & & \\
\hline 29 & $\begin{array}{l}\text { Existing courts are standard } \\
\text { and well prepared }\end{array}$ & 55 & 67.1 & 27 & 32.9 & - & - & 2.67 & 0.47 & 0.74 & 219 & 89 \\
\hline 30 & $\begin{array}{c}\text { There are enough number } \\
\text { of tennis courts to easily } \\
\text { practice tennis }\end{array}$ & 49 & 59.8 & 31 & 37.8 & 2 & 2.4 & 2.57 & 0.55 & 0.77 & 211 & 86 \\
\hline 31 & $\begin{array}{c}\text { The administrative system } \\
\text { of the club provides } \\
\text { facilities for players }\end{array}$ & 40 & 48.8 & 27 & 32.9 & 15 & 18.3 & 2.3 & 0.76 & 0.58 & 189 & 77 \\
\hline 32 & $\begin{array}{l}\text { Routine and administrative } \\
\text { complexity are not applied } \\
\text { in the club }\end{array}$ & 48 & 58.5 & 34 & 41.5 & - & - & 2.59 & 0.50 & 0.35 & 212 & 86 \\
\hline 33 & $\begin{array}{c}\text { The club offers skillful } \\
\text { workers in setting up and } \\
\text { maintenance of the tennis } \\
\text { courts }\end{array}$ & 48 & 58.5 & 22 & 26.8 & 12 & 14.6 & 2.44 & 0.74 & 0.92 & 200 & 81 \\
\hline 34 & $\begin{array}{l}\text { Tennis courts are equipped } \\
\text { with lights, benches and } \\
\text { umbrellas for breaks during } \\
\text { training }\end{array}$ & 56 & 68.3 & 17 & 20.7 & 9 & 11 & 2.57 & 0.69 & $\begin{array}{c}1.33 \\
3\end{array}$ & 211 & 86 \\
\hline 35 & $\begin{array}{l}\text { The club sponsored the } \\
\text { players who represent it }\end{array}$ & 30 & 36.6 & 30 & 36.6 & 22 & 26.8 & 2.10 & 0.79 & 0.18 & 172 & 70 \\
\hline 36 & $\begin{array}{c}\text { The club administration is } \\
\text { of a high level of } \\
\text { professionalism in the } \\
\text { management of activity }\end{array}$ & 28 & 34.1 & 45 & 54.9 & 9 & 11 & 2.23 & 0.63 & 0.23 & 183 & 74 \\
\hline 37 & $\begin{array}{c}\text { The club pays the players' } \\
\text { entry fees in the tennis } \\
\text { championships }\end{array}$ & 33 & 40.2 & 17 & 20.7 & 32 & 39 & $\begin{array}{c}2.01 \\
2\end{array}$ & 0.90 & 0.24 & 165 & 67 \\
\hline 38 & $\begin{array}{l}\text { The administrative } \\
\text { personnel in the club carry } \\
\text { out the administrative } \\
\text { procedures of the tennis } \\
\text { federation players }\end{array}$ & 39 & 47.6 & 43 & 52.4 & - & - & 2.48 & 0.50 & 0.1 & 203 & 83 \\
\hline 39 & $\begin{array}{c}\text { Club provides sufficient } \\
\text { number of changing rooms } \\
\text { and bathrooms }\end{array}$ & 53 & 64.6 & 11 & 13.4 & 18 & 22 & 2.43 & 0.83 & 0.95 & 199 & 81 \\
\hline 40 & $\begin{array}{l}\text { Club provides the needs of } \\
\text { the club rooms e.g clothing } \\
\text { and Sport instruments }\end{array}$ & 6 & 7.3 & 34 & 41.5 & 42 & 51.2 & 1.56 & 0.63 & 0.67 & 128 & 52 \\
\hline 41 & $\begin{array}{c}\text { The team players are } \\
\text { supplied by meals during } \\
\text { championships }\end{array}$ & 29 & 35.4 & 13 & 15.9 & 40 & 48.8 & 1.87 & 0.91 & 0.27 & 153 & 62 \\
\hline 42 & $\begin{array}{l}\text { The club offers medical } \\
\text { units and ambulance for } \\
\text { players }\end{array}$ & 27 & 32.9 & 41 & 50 & 14 & 17.1 & 2.16 & 0.69 & 0.22 & 177 & 72 \\
\hline 43 & $\begin{array}{l}\text { The club provides parking } \\
\text { for its members }\end{array}$ & 50 & 61 & 30 & 36.6 & 2 & 2.4 & 2.85 & 0.45 & 0.82 & 212 & 86 \\
\hline
\end{tabular}




\begin{tabular}{|c|c|c|c|c|c|c|c|c|c|c|c|c|}
\hline \multirow{2}{*}{$\mathbf{S}$} & \multirow{2}{*}{ Questionnaire statements } & \multicolumn{2}{|c|}{ Yes } & \multicolumn{2}{|c|}{$\begin{array}{l}\text { To some } \\
\text { extend }\end{array}$} & \multicolumn{2}{|c|}{ No } & \multirow{2}{*}{$\stackrel{\Xi}{\Xi}$} & \multirow{2}{*}{ تَّ } & \multirow{2}{*}{ 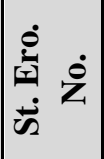 } & \multirow{2}{*}{ हैं } & \multirow{2}{*}{$b^{\circ}$} \\
\hline & & No. & $\%$ & No. & $\%$ & No. & $\%$ & & & & & \\
\hline 44 & $\begin{array}{l}\text { There is a facilities in } \\
\text { accepting new members of } \\
\text { tennis players }\end{array}$ & 44 & 53.7 & 34 & 41.5 & 4 & 4.9 & 2.49 & 0.59 & 0.68 & 204 & 83 \\
\hline 45 & $\begin{array}{c}\text { There is a fitness room in } \\
\text { the club }\end{array}$ & 68 & 82.9 & 6 & 7.3 & 8 & 9.8 & 2.74 & 0.63 & 2.16 & 224 & 91 \\
\hline
\end{tabular}

Table (7) shows the answers of the sample of players and parents on the facility and capabilities domain. The following are the sentences that obtain high marks:

- There is a fitness room in the club

- Existing courts are well prepared

- Routine is not applied in the club

- There are enough number of tennis courts

- Tennis courts are equipped with lights, benches and umbrellas which assure the existence of facilities and providing capabilities for tennis players which increase their number in these clubs
While the statements that obtain low marks were as follow:

- The team players are supplied by meals during championships

- The club pays the players' entry fees in the tennis championships

- The club sponsored the players who represent it

In the researcher's opinion this is because of the players don't depend on the club meals because most of the tennis players are from high economical level and doesn't care for the financial support as their parents cover all expenses

Table (8)

The statistical descriptions and the percentages of the sample's answers from coaches and officials on the financial domain

\begin{tabular}{|c|c|c|c|c|c|c|c|c|c|c|c|c|}
\hline \multirow[t]{2}{*}{$\mathbf{S}$} & \multirow{2}{*}{$\begin{array}{l}\text { Questionnaire } \\
\text { statements }\end{array}$} & \multicolumn{2}{|c|}{ Yes } & \multicolumn{2}{|c|}{$\begin{array}{l}\text { To some } \\
\text { extend }\end{array}$} & \multicolumn{2}{|c|}{ No } & \multirow{2}{*}{ ‡્ઞ } & \multirow{2}{*}{ تே } & \multirow{2}{*}{ 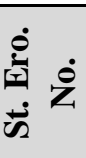 } & \multirow{2}{*}{ हैं } & \multirow{2}{*}{ de $\dot{z}$} \\
\hline & & No. & $\%$ & No. & $\%$ & No. & $\%$ & & & & & \\
\hline 1 & $\begin{array}{c}\text { Sport gears are well } \\
\text { marketed during tennis } \\
\text { activity }\end{array}$ & 23 & 82.1 & 5 & 17.9 & - & - & 2.60 & 0.78 & 1.78 & 74 & 88 \\
\hline 2 & $\begin{array}{c}\text { The club realizes huge } \\
\text { profits from selling tennis } \\
\text { instruments }\end{array}$ & 7 & 25 & 19 & 67.9 & 2 & 7.1 & 2.18 & 0.55 & 0.12 & 61 & 73 \\
\hline 3 & $\begin{array}{c}\text { The club realizes profits } \\
\text { through renting tennis } \\
\text { court }\end{array}$ & 15 & 53.6 & 13 & 46.4 & - & - & 2.54 & 0.51 & 0.15 & 71 & 85 \\
\hline 4 & $\begin{array}{l}\text { There is an increase in } \\
\text { the demand for } \\
\text { membership of the club } \\
\text { due to the presence of the } \\
\text { tennis courts }\end{array}$ & 13 & 46.4 & 10 & 35.7 & 5 & 17.9 & 2.29 & 0.76 & 0.55 & 64 & 76 \\
\hline
\end{tabular}




\begin{tabular}{|c|c|c|c|c|c|c|c|c|c|c|c|c|}
\hline \multirow[t]{2}{*}{$\mathbf{S}$} & \multirow{2}{*}{$\begin{array}{l}\text { Questionnaire } \\
\text { statements }\end{array}$} & \multicolumn{2}{|c|}{ Yes } & \multicolumn{2}{|c|}{$\begin{array}{l}\text { To some } \\
\text { extend }\end{array}$} & \multicolumn{2}{|c|}{ No } & \multirow{2}{*}{$\stackrel{\Xi}{\Xi}$} & \multirow{2}{*}{ 苛 } & \multirow{2}{*}{ 这 } & \multirow{2}{*}{$\overbrace{}^{\frac{\pi}{\theta}}$} & \multirow{2}{*}{$\Delta \circ$} \\
\hline & & No. & $\%$ & No. & $\%$ & No. & $\%$ & & & & & \\
\hline 5 & $\begin{array}{l}\text { The financial return of } \\
\text { tennis activity helps in the } \\
\text { setting up and } \\
\text { maintenance of the courts }\end{array}$ & 24 & 85.7 & 2 & 7.1 & 2 & 7.1 & 2.79 & 0.57 & 2.64 & 78 & 93 \\
\hline 6 & $\begin{array}{c}\text { There are ads at the club } \\
\text { which provide } \\
\text { appropriate financial } \\
\text { income }\end{array}$ & 14 & 50 & 12 & 42.9 & 2 & 7.1 & 2.43 & 0.63 & 0.65 & 68 & 81 \\
\hline 7 & $\begin{array}{l}\text { The restaurants and } \\
\text { cafeterias of the club } \\
\text { realize financial profits } \\
\text { through tennis comers }\end{array}$ & 16 & 57.1 & 7 & 25 & 4 & 14.3 & 2.44 & 0.75 & 0.97 & 66 & 79 \\
\hline 8 & $\begin{array}{c}\text { It is allowed for coaches to } \\
\text { train players on a paid } \\
\text { basis }\end{array}$ & 25 & 89.3 & 3 & 10.7 & - & - & 2.89 & 0.31 & 2.69 & 81 & 96 \\
\hline 9 & $\begin{array}{l}\text { The coaches obtain } \\
\text { profitable salaries }\end{array}$ & 11 & 39.3 & 17 & 10.7 & - & - & 2.39 & 0.50 & 0.46 & 67 & 80 \\
\hline 10 & $\begin{array}{l}\text { Tennis championships } \\
\text { realize great revenues for } \\
\text { the club }\end{array}$ & 16 & 57.1 & 6 & 21.4 & 6 & 21.4 & 2.36 & 0.83 & 0.78 & 66 & 79 \\
\hline
\end{tabular}

Table (8) shows the answers of the sample of coaches and officials on the financial domain. The following are the sentences that obtain high marks:

- It is allowed for coaches to train players on a paid basis

- The financial return of tennis activity helps in the setting up and maintenance of the courts

- Club realize revenues through renting tennis Courts
- All of the above confirm that the club realizes profits through practicing tennis and its activities

- While the statements that obtain low marks were as follow:

- The club realizes huge profits from selling tennis instruments as the club don't basically depend on selling these instruments and throughout the experience of the researcher he found out that most of the private club rent inside units for sport gears brands 
Table (9)

The statistical descriptions and the percentages of the sample's answers from coaches and officials on the technical domain

\begin{tabular}{|c|c|c|c|c|c|c|c|c|c|c|c|c|}
\hline \multirow{2}{*}{$\mathbf{S}$} & \multirow{2}{*}{ Questionnaire statements } & \multicolumn{2}{|c|}{ Yes } & \multicolumn{2}{|c|}{$\begin{array}{l}\text { To some } \\
\text { extend }\end{array}$} & \multicolumn{2}{|c|}{ No } & \multirow{2}{*}{ ఏ్ } & \multirow{2}{*}{ 芦苞 } & \multirow{2}{*}{$\stackrel{\dot{0}}{\dot{\omega}}$} & \multirow{2}{*}{ 吾 } & \multirow{2}{*}{$\dot{z}$} \\
\hline & & No. & $\%$ & No. & $\%$ & No. & $\%$ & & & & & \\
\hline 11 & $\begin{array}{c}\text { The tennis training } \\
\text { programs of the club are } \\
\text { well prepared }\end{array}$ & 22 & 78.6 & 6 & 2.4 & - & - & 2.79 & 0.42 & 1.47 & 78 & 93 \\
\hline 12 & $\begin{array}{c}\text { There are special training } \\
\text { programs for high-level } \\
\text { players }\end{array}$ & 22 & 78.6 & 4 & 14.3 & 2 & 7.1 & 2.71 & 0.60 & 2.04 & 76 & 90 \\
\hline 13 & $\begin{array}{l}\text { High level coaches carry } \\
\text { out the coaching process }\end{array}$ & 20 & 71.4 & 8 & 28.6 & - & - & 2.71 & 0.46 & 1.03 & 76 & 90 \\
\hline 14 & $\begin{array}{l}\text { Training program at the } \\
\text { club consider the } \\
\text { academic periods of the } \\
\text { players }\end{array}$ & 21 & 75 & 7 & 25 & - & - & 2.75 & 0.44 & 1.22 & 77 & 92 \\
\hline 15 & $\begin{array}{l}\text { Training programs help } \\
\text { players to participate in } \\
\text { championships }\end{array}$ & 22 & 78.6 & 6 & 21.4 & - & - & 2.79 & 0.42 & 1.47 & 78 & 93 \\
\hline 16 & $\begin{array}{l}\text { The club follow up the } \\
\text { players through their } \\
\text { participation in } \\
\text { competition and } \\
\text { championships }\end{array}$ & 19 & 67.9 & 9 & 32.1 & - & - & 2.68 & 0.48 & 8.09 & 75 & 89 \\
\hline 17 & $\begin{array}{l}\text { The club administration } \\
\text { follows up the players } \\
\text { technical level on a } \\
\text { regular basis }\end{array}$ & 18 & 64.3 & 6 & 21.4 & 4 & 14.3 & 2.5 & 0.75 & 1.16 & 70 & 83 \\
\hline 18 & $\begin{array}{c}\text { The club organize internal } \\
\text { competition to identify the } \\
\text { level of the players }\end{array}$ & 19 & 67.9 & 7 & 25 & 2 & 7.1 & 2.61 & 0.63 & 1.40 & 73 & 87 \\
\hline 19 & $\begin{array}{l}\text { The club uses modern } \\
\text { methods in training }\end{array}$ & 17 & 60.9 & 9 & 32.1 & 2 & 7.1 & 2.54 & 0.64 & 1.07 & 71 & 85 \\
\hline 20 & $\begin{array}{c}\text { The club conduct } \\
\text { periodical examinations to } \\
\text { identify the level of the } \\
\text { players }\end{array}$ & 19 & 67.9 & 9 & 32.1 & - & - & 2.68 & 0.48 & 0.81 & 75 & 89 \\
\hline 21 & $\begin{array}{c}\text { The club administration } \\
\text { organizes educational } \\
\text { programs to upgrade the } \\
\text { coaches }\end{array}$ & 15 & 53.6 & 7 & 25 & 6 & 21.4 & 2.32 & 0.82 & 0.68 & 65 & 77 \\
\hline 22 & $\begin{array}{l}\text { The educational videos } \\
\text { are used in coaching the } \\
\text { club's members }\end{array}$ & 2 & 7.1 & 9 & 32.1 & 7 & 60.7 & 1.46 & 0.64 & 1.07 & 41 & 48 \\
\hline
\end{tabular}

Table (9) shows the answers of the sample of coaches and officials on the technical domain. The following are the sentences that obtain high marks:
- Training programs for tennis on the club are well prepared

- Training program at the club help the players and consider their academic periods 
- Highly qualified coaches are While the statements that obtain low marks responsible for training players

- Training programs help players to reach high skillful level

- There are training programs in the club for high level players

All of the above emphasis the importance of were as follow:

- The educational videos are used in coaching the club's members

As they don't care for educational videos and they depend upon the practical coaching at the court the technical aspects of tennis.

Table (10)

The statistical descriptions and the percentages of the sample's answers from coaches and officials on the facilities and capabilities domain

\begin{tabular}{|c|c|c|c|c|c|c|c|c|c|c|c|c|}
\hline \multirow{2}{*}{$\mathbf{S}$} & \multirow{2}{*}{$\begin{array}{c}\text { Questionnaire } \\
\text { statements }\end{array}$} & \multicolumn{2}{|c|}{ Yes } & \multicolumn{2}{|c|}{$\begin{array}{l}\text { To some } \\
\text { extend }\end{array}$} & \multicolumn{2}{|c|}{ No } & \multirow{2}{*}{ 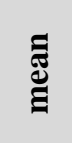 } & \multirow{2}{*}{ ثं } & \multirow{2}{*}{ 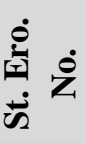 } & \multirow{2}{*}{ 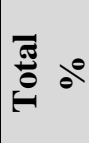 } & \multirow{2}{*}{ se $\dot{z}$} \\
\hline & & No. & $\%$ & No. & $\%$ & No. & $\%$ & & & & & \\
\hline 23 & $\begin{array}{c}\text { The club's administrative } \\
\text { system encourages } \\
\text { workers for good } \\
\text { performance }\end{array}$ & 17 & 60.7 & 9 & 32.1 & 2 & 7.1 & 2.54 & 0.64 & 1.07 & 71 & 85 \\
\hline 24 & $\begin{array}{l}\text { the club's adminitration } \\
\text { treat its staff in a } \\
\text { respectful manner and } \\
\text { appreciation }\end{array}$ & 21 & 75 & 7 & 25 & - & - & 2.75 & 0.44 & 1.22 & 77 & 92 \\
\hline 25 & $\begin{array}{l}\text { The club's administrative } \\
\text { system encourages } \\
\text { employees for innovation } \\
\text { and creativity }\end{array}$ & 19 & 67.9 & 6 & 21.4 & 3 & 10.7 & 2.57 & 0.69 & 1.37 & 72 & 86 \\
\hline 26 & $\begin{array}{c}\text { The club offers facilities } \\
\text { for its employees } \\
\text { (transportation- uniform - } \\
\text { meals) }\end{array}$ & 11 & 39.3 & 9 & 32 & 8 & 28.6 & 2.11 & 0.83 & 0.21 & 59 & 70 \\
\hline 27 & $\begin{array}{l}\text { The club offers the } \\
\text { coaches requirements e.g. } \\
\text { helping tools in coaching }\end{array}$ & 20 & 71.4 & 9 & 28.6 & - & - & 2.71 & 0.46 & 1 & 76 & 90 \\
\hline 28 & $\begin{array}{l}\text { office hours of the club } \\
\text { helps coaches for good } \\
\text { work }\end{array}$ & 24 & 85.7 & 8 & 7.1 & 2 & 7.1 & 2.73 & 0.57 & 2.64 & 78 & 93 \\
\hline 29 & $\begin{array}{l}\text { Incentives are provided } \\
\text { for serious coaches }\end{array}$ & 17 & 60.7 & 2 & 25 & 4 & 14.3 & 2.46 & 0.74 & 1.03 & 69 & 82 \\
\hline 30 & $\begin{array}{c}\text { There are appropriate } \\
\text { number of maintenance } \\
\text { workers at the club }\end{array}$ & 16 & 57.1 & 7 & 35.7 & 2 & 7.1 & 2.5 & 0.64 & 0.92 & 70 & 83 \\
\hline 31 & $\begin{array}{c}\text { The club provides an } \\
\text { appropriate number of } \\
\text { rooms for coaches to save } \\
\text { their stuff }\end{array}$ & 17 & 60.3 & 10 & 17.9 & 6 & 21.4 & 2.39 & 0.83 & 0.88 & 67 & 70 \\
\hline 32 & $\begin{array}{l}\text { Workers' salaries will be } \\
\text { paid regularly in a timely } \\
\text { manner }\end{array}$ & 22 & 78.6 & 5 & 14.3 & 2 & 7.1 & 2.71 & 0.60 & 2.04 & 76 & 90 \\
\hline
\end{tabular}




\begin{tabular}{|c|c|c|c|c|c|c|c|c|c|c|c|c|}
\hline \multirow[t]{2}{*}{$\mathbf{s}$} & \multirow{2}{*}{$\begin{array}{l}\text { Questionnaire } \\
\text { statements }\end{array}$} & \multicolumn{2}{|c|}{ Yes } & \multicolumn{2}{|c|}{$\begin{array}{l}\text { To some } \\
\text { extend }\end{array}$} & \multicolumn{2}{|c|}{ No } & \multirow{2}{*}{ 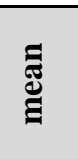 } & \multirow{2}{*}{ 苛 } & \multirow{2}{*}{ 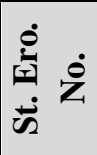 } & \multirow{2}{*}{$\overbrace{}^{\pi}$} & \multirow[t]{2}{*}{ of $\dot{z}$} \\
\hline & & No. & $\%$ & No. & $\%$ & No. & $\%$ & & & & & \\
\hline 33 & $\begin{array}{l}\text { Club provides insurance } \\
\text { and health insurance for } \\
\text { workers }\end{array}$ & 13 & 46.4 & 4 & 39.3 & 4 & 14.3 & 2.32 & 0.72 & 0.58 & 65 & 77 \\
\hline 34 & $\begin{array}{c}\text { Courts of the club are } \\
\text { working in a timely } \\
\text { manner }\end{array}$ & 24 & 85.7 & 11 & 14.3 & - & - & 2.86 & 0.36 & 2.16 & 80 & 95 \\
\hline 35 & $\begin{array}{l}\text { There are appropriate } \\
\text { number of courts at the } \\
\text { club that help in working }\end{array}$ & 21 & 75 & 4 & 10.7 & 4 & 14.3 & 2.61 & 0.74 & 1.59 & 73 & 87 \\
\hline 36 & $\begin{array}{l}\text { Routine administrative } \\
\text { and bureaucracy are not } \\
\text { used in the Club }\end{array}$ & 16 & 57.1 & 3 & 14.3 & 8 & 28.6 & 2.29 & 0.90 & $\begin{array}{c}0.62 \\
3\end{array}$ & 64 & 76 \\
\hline 37 & $\begin{array}{l}\text { Club administration used } \\
\text { modern methods of } \\
\text { administration }\end{array}$ & 20 & 71.4 & 8 & 28.6 & - & - & 2.71 & 0.46 & 1 & 76 & 90 \\
\hline
\end{tabular}

Table (10) shows the answers of the sample of coaches and officials on the facilities and capabilities domain. The following are the sentences that obtain high marks:

- The setting up of the courts are properly done and according to the standards

- The club's administrative system encourages employees for innovation and creativity

- Office hours of the club helps coaches for good work

- Workers' salaries will be paid regularly in a timely manner

- Club administration used modern methods of administration

All the above confirm that there are a lot of facilities and capabilities in the club

While the statements that obtain low marks were as follow:

- The club offers facilities for its employees (transportation- uniform meals)
The researcher analyzes that it could be done by allowances with salary due to the few number of workers in private clubs. $(1)(7)(9)(10)(11)(12)(13)$

\section{The Conclusions:}

Within the limits of the research sample and through the research results the following are shown:

First: For the performance of the research sample of players and parents

1. Playing tennis at the private clubs achieves the following financial returns:

- Providing special paid training sessions

- The financial profits attain by the restaurants and cafeterias of the club

- Profits achieve by renting the tennis courts 
- There is an increases of demand for membership in the club because of the presence of tennis courts

2. Tennis championships and marketing of sport gear realize medium profits medium for private clubs

3. Methods and technical aspects that are provided by private clubs for tennis activity are as follow:

- Providing great efficient coaches in basic skills and fitness

- Training programs are well prepared and help the players to participate in championships .

4. The administration of the private club follow up the technical levels of the players and help them to participate in international championships in an average level .

5. Using educational videos and modern instruments are not activated as required.

6. The facilities and capabilities that are provided by private clubs for tennis players as followed:

- Well preparation of standard courts that are supplied with seats and other things.

- Providing fitness halls -parking

- Qualified workers for setting up and maintenance of courts

- Providing an appropriate number of changing rooms and bathrooms.

7. There are administration facilities which are represented in avoiding routine and administration complication and providing administrative service for players through contacting tennis federation
8. Sponsoring the players who represent the club by providing them with what they need of sport gears and meals as well as participating in championships

Second: for the opinion of the research sample of coaches and parents

1. Playing tennis in private clubs realize financial return through the following: :

- Provide special paid training for players

- Renting tennis courts

- Marketing for tennis gears

- Advertisements of the club

- The restaurants and cafeterias that provide services for members

- Organizing tennis championships

- There is an increases of demand for membership in the club

2. The salaries of workers of the private club are reasonable and profitable

3. Methods and technical aspects that are provided by private clubs are as follow:

- Provide good training programs that helps players to reach high level of practice

- Provide programs that take care of the players' circumstanced

- Provide high skillful coaches for all levels

- Providing coaching requirements

- Organizing internal competition

- conduct periodical examinations to identify the level of the players and follow up them 
- Organize coaching courses to upgrade the coaches' level

4. Using educational videos in coaching is not activated

5. The facilities and capabilities that are provided by private clubs for tennis players are as follow:

- Provide appropriate number of standard courts

- The working hours of coaches help them to work hard

- Provide appropriate number of workers and tennis ball boy

- Provide coaches with their requirements e.g. helping tools in training

- Club administrative system encourages good performance of workers

- The club's administration treat its staff in a respectful manner and appreciation

- Workers' salaries will be paid regularly in a timely manner

6. The club offers facilities for its employees (transportation- uniform meals- medical insurance)

\section{The Recommendations}

Throughout the results of the research, the researcher recommends the following:

1. Promoting the establishment of a private tennis clubs because of what they offer of facilities for the players of tennis

2. Promoting the investment in the field of sports, especially tennis, due to the fact that it is not depend on the governmental support in addition it offers profitable services.

3. Given care for the high level education of tennis coaches in order to promote the sport of tennis and identify special qualifications of tennis coaches

4. Increasing interest in teaching tennis and its specialization in faculty of Physical Education to meet the need of the labor market in tennis sports training

5. Promoting competition between public and private sports clubs, in order to prepare and qualify players at a high level of tennis skills.

6. Providing facilities for clubs that achieve significant levels in winning championships and qualification of players

7. Activating the use of educational videos for players and using the modern teaching and training methods in the clubs.

8. Providing incentives for players, coaches, holders of high places and high skillful players

9. Providing insurance services, treatment and nutrition for coaches and administrators of the private clubs. 


\section{References:}

1. Ahmed Abdel Fatah Ahmed Salem (2004) :The economic and social implications for the privatization of sports clubs, unpublished Ph.D. Faculty of Physical Education for Boys, Helwan University.

2. Ahmed Farouk Abdel Kader (2000): The economic return to professional sports in some group sports activities, Unpublished Master, Faculty of Physical Education Helwan University, P.3.

3. Ahmed Farouk Abdel Kader (2005): The return of economic, political and social of the government spending on sports on the Arab Republic of Egypt, unpublished Ph.D., Faculty of Physical Education for Boys, Helwan University, P. 16 .

4. Kamal El Din Abdel Rahman Darwish, Ashraf Abdel Moez Abu Al Noor (2000): Sport Non-governmental organizations, Friends library, Cairo, P. 11 .

5. Kamal El Din Abdel Rahman Darwish, Mohamed Sobhy Hassanein (2004): Encyclopedia of sports administration at the beginning of the new century, Volume III, modern Marketing and Communications and the dynamic of human performance, the Arab Publishing House, Cairo, P. 17

6. Abdul Hafiz Abdullah, Sayed Taha Badawi (2004): The Origins of the economy, the Arab Renaissance House, Cairo, P. 41 .

7. Mohamed Sultan Abu Ali, Hanna Khair Eddine (1993): Origins of theory and practice economics, library of the Middle renaissance, Ain Shams University.

8. Mohamed Ali Abdel Moneim Hassan alBanna (2010): Evaluation study of private sports clubs for the Arab Republic of Egypt,
Unpublished Master, Faculty of Physical Education for Boys, Helwan University.

9. Mostafa Ahmed Sayed Ibrahim Azzam (2008): The economic return for the television rights of the sports clubs, unpublished Ph.D. , Faculty of Physical Education for Boys, Helwan University

10. Behunin, $\operatorname{Carl}(2010)$ :Economic impact of youth Sports: Hosting Baseball and softball tournaments in amid-south Community, Arkansas state university .

11. Mcternan,Jamesa.(2011):The economic value of whitewater sports in the cache la povdrecanyon,Colorado,Colorado stateuniversity

12. Mongeon,Kevinp(2010):Economic competition and the production of winning in professional sports-washingion state university.

13. Paulrud,Anton(2004):Economic valuation of sport- Fishing in Sweden;Empirical Findings and Methodological developments. Sverigeslantbrksuniversitet (Sweden). 


\section{The Questionnaire from players and parents on the financial domain}

\begin{tabular}{|c|c|c|c|c|}
\hline$\dot{\mathbf{z}}$ & Questionnaire statements & $\stackrel{\Xi}{\beth}$ & 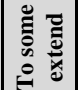 & $\stackrel{2}{z}$ \\
\hline 1 & Practicing tennis realize profits for the club & & & \\
\hline 2 & Marketing for sport gear is fully done through the activity of tennis & & & \\
\hline 3 & The club realizes huge profits by selling tennis instruments & & & \\
\hline 4 & Club realize revenues through renting Tennis Courts & & & \\
\hline 5 & There is an increases of demand for membership in the club because of the presence of tennis courts & & & \\
\hline 6 & Financial return of tennis activity helps in setting up and maintenance of the courts & & & \\
\hline 7 & There are ads at the club which realize an appropriate financial income & & & \\
\hline 8 & The restaurants and cafeterias of the club realize financial profits & & & \\
\hline 9 & There are paid private training sessions in the club & & & \\
\hline 10 & Tennis championships realize great revenues for the club & & & \\
\hline 11 & The club offers financial incentives for winners of tennis championships & & & \\
\hline 12 & Annual fees of the club are reasonable for members & & & \\
\hline 13 & Training programs for tennis on the club are well prepared & & & \\
\hline 14 & The club offers qualified coaches for tennis players & & & \\
\hline 15 & Training programs help players to reach higher skillful level & & & \\
\hline 16 & There are training programs in the club for high level players & & & \\
\hline 17 & Highly qualified coaches are responsible for training players & & & \\
\hline 18 & Training program at the club consider the academic periods of the players & & & \\
\hline 19 & The training programs help players to participate in the championships & & & \\
\hline 20 & The club administration continuously follow up the technical level of the players & & & \\
\hline 21 & The club follow up the players during their participation in competition and championships & & & \\
\hline 22 & The club organize internal competition to identify the level of the players & & & \\
\hline 23 & The club uses modern methods in training & & & \\
\hline 24 & The club conduct periodical examinations to identify the level of the players & & & \\
\hline 25 & The club supports the players to take part in the international championships & & & \\
\hline 26 & The educational videos are used in coaching the club's members & & & \\
\hline 27 & The club provides fitness coaches for players & & & \\
\hline 28 & The club offers specialist for the rehabilitation of injuries and treatment & & & \\
\hline 29 & Existing courts are standard and well prepared & & & \\
\hline 30 & There are enough number of tennis courts to easily practice tennis & & & \\
\hline 31 & The administrative system of the club provides facilities for players & & & \\
\hline 32 & Routine and administrative complexity are not applied in the club & & & \\
\hline 33 & The club offers skillful workers in setting up and maintenance of the tennis courts & & & \\
\hline 34 & Tennis courts are equipped with lights, benches and umbrellas for breaks during training & & & \\
\hline 35 & The club sponsored the players who represent it & & & \\
\hline 36 & The club administration is of a high level of professionalism in the management of activity & & & \\
\hline 37 & The club pays the players' entry fees in the tennis championships & & & \\
\hline 38 & The administrative personnel in the club carry out the administrative procedures of the tennis federation players & & & \\
\hline 39 & Club provides sufficient number of changing rooms and bathrooms & & & \\
\hline 40 & Club provides the needs of the club rooms e.g clothing and Sport instruments & & & \\
\hline 41 & The team players are supplied by meals during championships & & & \\
\hline 42 & The club offers medical units and ambulance for players & & & \\
\hline 43 & The club provides parking for its members & & & \\
\hline 44 & There is a facilities in accepting new members of tennis players & & & \\
\hline 45 & There is a fitness room in the club & & & \\
\hline
\end{tabular}




\section{The Questionnaire from coaches and officials on the financial domain}

\begin{tabular}{|c|c|c|c|c|}
\hline$\dot{\dot{z}}$ & Questionnaire statements & $\stackrel{y}{z}$ & 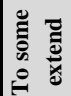 & z \\
\hline 1 & Sport gears are well marketed during tennis activity & & & \\
\hline 2 & The club realizes huge profits from selling tennis instruments & & & \\
\hline 3 & The club realizes profits through renting tennis court & & & \\
\hline 4 & There is an increase in the demand for membership of the club due to the presence of the tennis courts & & & \\
\hline 5 & The financial return of tennis activity helps in the setting up and maintenance of the courts & & & \\
\hline 6 & There are ads at the club which provide appropriate financial income & & & \\
\hline 7 & The restaurants and cafeterias of the club realize financial profits through tennis comers & & & \\
\hline 8 & It is allowed for coaches to train players on a paid basis & & & \\
\hline 9 & The coaches obtain profitable salaries & & & \\
\hline 10 & Tennis championships realize great revenues for the club & & & \\
\hline 11 & The tennis training programs of the club are well prepared & & & \\
\hline 12 & There are special training programs for high-level players & & & \\
\hline 13 & High level coaches carry out the coaching process & & & \\
\hline 14 & Training program at the club consider the academic periods of the players & & & \\
\hline 15 & Training programs help players to participate in championships & & & \\
\hline 16 & The club follow up the players through their participation in competition and championships & & & \\
\hline 17 & The club administration follows up the players technical level on a regular basis & & & \\
\hline 18 & The club organize internal competition to identify the level of the players & & & \\
\hline 19 & The club uses modern methods in training & & & \\
\hline 20 & The club conduct periodical examinations to identify the level of the players & & & \\
\hline 21 & The club administration organizes educational programs to upgrade the coaches & & & \\
\hline 22 & The educational videos are used in coaching the club's members & & & \\
\hline 23 & The club's administrative system encourages workers for good performance & & & \\
\hline 24 & the club's administration treat its staff in a respectful manner and appreciation & & & \\
\hline 25 & The club's administrative system encourages employees for innovation and creativity & & & \\
\hline 26 & The club offers facilities for its employees (transportation- uniform -meals) & & & \\
\hline 27 & The club offers the coaches requirements e.g. helping tools in coaching & & & \\
\hline 28 & office hours of the club helps coaches for good work & & & \\
\hline 29 & Incentives are provided for serious coaches & & & \\
\hline 30 & There are appropriate number of maintenance workers at the club & & & \\
\hline 31 & The club provides an appropriate number of rooms for coaches to save their stuff & & & \\
\hline 32 & Workers' salaries will be paid regularly in a timely manner & & & \\
\hline 33 & Club provides insurance and health insurance for workers & & & \\
\hline 34 & Courts of the club are working in a timely manner & & & \\
\hline 35 & There are appropriate number of courts at the club that help in working & & & \\
\hline 36 & Routine administrative and bureaucracy are not used in the Club & & & \\
\hline 37 & Club administration used modern methods of administration & & & \\
\hline
\end{tabular}


